\title{
Anti-fat attitudes of Nutrition undergraduates in Brazil toward individuals with obesity
}

\author{
Atitudes negativas em relação à obesidade por estudantes \\ de Nutrição do Brasil
}

Marle dos Santos Alvarenga (https://orcid.org/0000-0001-6922-2670) ${ }^{1}$

Angélica Almeida Obara (https://orcid.org/0000-0003-4985-2397) ${ }^{2}$

Gabriela Akemi Takeda (https://orcid.org/0000-0003-2806-640X) ${ }^{2}$

Sandra Roberta Gouvea Ferreira-Vivolo (https://orcid.org/0000-0002-7015-7391) ${ }^{2}$

${ }^{1}$ Programa de PósGraduação em Nutrição em Saúde Pública, Faculdade de Saúde Pública, Universidade de São Paulo. Av. Dr. Arnaldo 715. 01246-904 São Paulo SP Brasil. marlealv@usp.br

${ }^{2}$ Faculdade de Saúde Pública, Universidade de São Paulo. São Paulo SP Brasil.

\begin{abstract}
Obesity-related prejudice and discrimination may have a source in health professionals and students. The objective was to assess anti-fat attitudes among Brazilian nutrition undergraduates who reported demographic data, weight, height and responded the Antifat Attitudes Test (AFAT) and the Brazilian Silhouette Scales to assess body image satisfaction and perception. Total and subscales of AFAT scores were compared among categories using the Mann-Whitney $U$ test. Associations of participants' characteristics with the AFAT were analyzed using multiple linear regression. Total AFAT score was positively associated with male sex $(\beta: .13 ; p<.001)$, age $(\beta: .06 ; p<.001)$, educational institution outside capital ( $\beta$ : .03; $p<.05)$, private institutions $(\beta$ : $.08 ; p<.001)$; and negatively associated with income ( $\beta$ : -.05; $p=.006)$, participants who perceived themselves with increased BMI ( $\beta$ : -.15 ; $p$ $<.001)$ and those at the third year of course $(\beta$ : $-.05 ; p=.041)$. Subscales scores were positively associated with male sex and age; and negatively associated with those who perceived themselves heavier. They have anti-fat attitudes especially if they were man, older, from private institutions, are at the beginning of the course, and have lower household income - and less weight bias if they perceived with increased BMI.
\end{abstract}

Key words Obesity, Nutritionists, Weight prejudice
Resumo O preconceito e a discriminação relacionados à obesidade podem vir de profissionais de saúde e estudantes. O objetivo foi avaliar as atitudes negativas em relação à obesidade entre universitários brasileiros de nutrição que relataram dados demográficos, peso, altura e responderam o Antifat Attitudes Test (AFAT) e a Escala de Silhuetas Brasileira para avaliar a satisfação e percepção da imagem corporal. Os escores total e das subescalas da AFAT foram comparados entre as categorias usando o teste U de Mann-Whitney. As associações das características dos participantes com a AFAT foram analisadas por meio de regressão linear múltipla. A pontuação total da AFAT foi positivamente associada ao sexo masculino ( $\beta$ : $0,13 ; p<0,001)$, idade ( $\beta: 0,06 ; p<0,001)$, instituições de ensino fora da capital $(\beta: 0,03 ; p<0,05)$ e instituições privadas ( $\beta$ : 0,$08 ; p<0,001)$; e negativamente associada à renda $(\beta:-0,05 ; p=0,006)$, participantes que se percebiam acima do IMC real $(\beta:-0,15 ; p<0,001)$ e do terceiro ano do curso ( $\beta$ : $-0,05 ; p=0,041)$. As pontuações das subescalas foram positivamente associadas com sexo masculino e idade; e negativamente associadas com aqueles que se percebiam mais pesados. Os estudantes tinham atitudes antigordura especialmente se eram homens, mais velhos, de instituições privadas, no começo do curso e baixa renda - e menos se percebiam seu IMC maior.

Palavras-chave Obesidade, Nutricionistas, Preconceito de peso 


\section{Introduction}

Considering that obesity is a major public health challenge, it is vital to deepen the understanding of socioemotional factors that make its control even more difficult. Some of these factors have their origin in society, but it is not clear how much health professionals themselves contribute to maintaining prejudice against individuals with obesity ${ }^{1-5}$. Discriminatory attitudes among health professionals - especially dietitians - have already been explored in some populations and less rarely among students ${ }^{4-12}$.

Stigma, bias and discrimination contribute to deleterious consequences in the psychological sphere ${ }^{1-18}$, adding or aggravating preexisting morbidities ${ }^{15,19,20}$ and limiting the access to health ${ }^{21-23}$. In Brazil, prevalence of obesity has increased considerably in the last decades, from $5.2 \%$ in 1975 to $22.1 \%$ in $2016^{24}$, but studies addressing its social consequences are $\operatorname{rare}^{25}$. A study conducted in Brazilian nutrition undergraduates using hypothetical case studies found that the patient's weight influenced the responses related to behaviors and prescriptions, biased to negative attitudes ${ }^{26}$. Such behaviors toward individuals with obesity and prejudice have been called weight bias and stigma ${ }^{27}$.

Considering that scenario and the vital role of dietitians in the treatment of obesity and comorbidities, it is of interest to identify early the existence of weight bias toward individuals with obesity among nutrition students when measures can be taken to avoid negative attitudes, before they began professional practice. Therefore, the present study aimed to investigate the presence of negative attitudes toward individuals with obesity among Brazilian nutrition undergraduates and identify with variables relating to subgroups which require more educational attention.

\section{Methods}

This is a sub-study of the Nutrition Health Study (NutriHS) carried out with nutrition undergraduates from the state of São Paulo, Brazil. Details on the purposes and methodological issues were previously reported ${ }^{28}$. The NutriHS was approved by the ethics committee of FSP-USP, and the participants electronically agreed to participate.

The eligibility criteria were being an undergraduate in Nutrition aged 18 to 40 years old. The sample size was calculated considering an effect size of $15 \%$ and $80 \%$ power, resulting in 218 plus $15 \%$ to compensate losses, totalizing 251 participants.

On the survey webpage, participants provided information on demographics: socioeconomic condition (in minimum wage bands options), sex, age, skin color (options including "I don't know" and "I prefer do not inform"), parent's educational level, household income, work (yes or no) and marital status (options); location and kind of university (public or private) and course year. They also give self-reported body weight and height - used to classify nutritional status by the body mass index - BMI, according to the World Health Organization ${ }^{29}$.

Negative attitudes toward obesity were evaluated using the Antifat Attitudes Test - AFAT with its total score and three subscales: 1 ) social and character disparagement (socially undesirable characteristics related to the personality of individuals with obesity and social contempt for them);2) physical and romantic unattractiveness (perception that people with obesity are clumsy and unacceptable as romantic partners); and 3) weight control and blame (belief that the weight of individuals with obesity is under their control, rather than being influenced by biological aspects) ${ }^{30}$. A systematic review on instruments that assess weight bias found that of 40 questionnaires, the AFAT is one that has higher quality of assessment ${ }^{31}$.

The version with 34 questions was transculturally adapted to Brazilian Portuguese language and showed good equivalence in all adaptation stages and presented adequate psychometric properties (Cronbach's alpha .85; Intraclass Correlation Coefficient .83$)^{32}$. The options for answers are given in a Likert-type scale of five points ranging from "Strongly disagree" and "Strongly agree"; the highest scores reflect more negative attitudes toward individuals with obesity.

Participants responded also the Brazilian Silhouettes $\mathrm{Scale}^{33}$ to assess body image satisfaction (difference between figure that represents the current body and the desired) and perception (actual BMI - based on self-reported weight and height - compared with BMI corresponding to the figure chose as representative). It comprises 15 figures, for which the BMI means range from 12.5 to $47.5 \mathrm{~kg} / \mathrm{m}^{2}$ presenting positive correlation for actual BMI and body perception. It is presented with questions: "Which figure best represents your current body?" and "... the body that you would like to have?"33. 


\section{Statistical analysis}

Characteristics were described by simple frequency distribution; continuous variables that did not exhibit normal distribution were also described by means of median and interquartile range $\left(\mathrm{IQ}_{25-75}\right)$. Age was categorized as below or above the median ( $<25$ years; $\geq 25$ years $)$; skin color as white or not white; parent's educational level as higher education or not; household income as below or above the median, considering minimum wages $-\mathrm{MW}(<6 \mathrm{MW}$ or $\geq 6 \mathrm{MW})$.

The type of distribution of the AFAT total and subscales scores was explored by means of the Shapiro Wilk's test. Those outcomes that did not present normal distribution (AFAT total score and for "Social Disparagement" and "Unattractiveness" subscales), the variables were converted to log form and then the normality of the transformed variables was checked, and the normality of the statistical residue, to meet the theoretical assumptions of linear models, was ensured. The "Weight Control" subscale was normally distributed and followed the regression model in its original form.

AFAT medians and subscales according to the categories of each independent variable were compared using the Mann Whitney test and Kruskal Wallis complemented with the Dunn's test for multiple comparisons.

Results of the body satisfaction and perception were presented in interquartile ranges and categorized as: 1) satisfaction/adequate perception $=$ no difference between actual and desired/ perceived body; 2) dissatisfaction due to a desired larger silhouette $=$ difference between actual and desired figures between -1 to -5 points; or if perceived as smaller $=$ difference between actual and perceived figure was -1 to -4 points; 3 ) dissatisfaction with a desire of a smaller silhouette or if perceived as larger $=$ difference of 1 to 2 points; 4 ) dissatisfaction with a desire of a much smaller silhouette or if perceived to be much larger $=$ difference of 3 to 12 points for dissatisfaction and 3 to 7 for perception. This variable was also presented in the dichotomic form to assess the frequency of desire of a smaller silhouette (yes or no).

Participants' characteristics associated with the outcomes (AFAT scores) were analyzed using the multiple linear regression model and adopting hierarchical selection of independent variables, which represents a coherent theoretical and analytical scheme, according to which the antecedent factors influence the consequent outcomes through a hierarchical structure of events.
Based on literature concerning stigma and bias toward obesity and the individual affected by obesity, a conceptual model was developed. Thus, at the distal level - positioned farther from the outcome of interest and "non-modifiable" demographic characteristics - were socioeconomic condition, sex, age (" $<25$ years; $\geq 25$ years"), skin color (white and not white), parent's educational level (higher education "yes or no"), household income (" $<6 \mathrm{MW}$ or $\geq 6 \mathrm{MW}$ "), work (yes or no) and marital status (with or without a partner).

To compose the multiple hierarchical modeling, firstly, bivariate (gross) linear regression analyses were performed between the outcome and each independent variable, and to enter the model were selected those with $p<0.20$. Only those that obtained $p<0.10$ in the joint analysis remained in the model and proceeded to the intermediate level (but only those with $p<0.05$ were considered significant). The intermediate level was made up by the variables that remained at the distal level, added by the variables relating to the student's nutritional status: BMI (underweight, normal weight, overweight or obesity), body perception (perception of BMI higher than it really is) and body dissatisfaction (relating to BMI higher than desirable), which, after tested jointly, remained in the model. Finally, the proximal level was comprised of the variables that remained at the intermediate level added by those related to the characteristics of the nutrition school - which act directly or immediately on the outcome: location (capital or elsewhere), kind of university (public or private) and course year (freshmen, $1^{\text {st }}$ and $2^{\text {nd }}$ year, $\geq 3^{\text {rd }}$ year).

The results of the linear regression model were presented by $B$ coefficients and 95\% confidence intervals. In all models, normality of residuals, multicollinearity and heteroskedasticity were checked using Shapiro Wilk, Durban Watson and Breusch-Pagan tests, respectively.

Data were analyzed using the Stata 13.0. software. Significance level was set at $p<0.05$.

\section{Results}

A total of 629 nutrition undergraduates, most female, aged below 25 years, single and working, participated in the study. Nearly $30 \%$ of the students' parents had higher educational level and monthly income over six MW. A comparison of AFAT medians revealed higher scores for male individuals, higher age, lower income and parent's fewer years of schooling (Table 1). 
Table 1. Antifat Attitudes Test (AFAT) median scores according with sociodemographic characteristics of Dietetic major students in São Paulo - Brazil $(\mathrm{n}=629)$.

\begin{tabular}{|c|c|c|c|}
\hline Variable & n (\%) & $\begin{array}{l}\text { AFAT median } \\
\text { (IQ 25-75) }\end{array}$ & $\mathbf{p}^{\star *}$ \\
\hline \multicolumn{4}{|l|}{ Sex } \\
\hline Female & $588(93.48)$ & $60(53 ; 69)$ & $<0.001$ \\
\hline Male & $41(6.52)$ & $69(62 ; 81)$ & \\
\hline \multicolumn{4}{|l|}{ Age (years) } \\
\hline$<25$ & $346(55.01)$ & $60(52 ; 68)$ & $<0.001$ \\
\hline$\geq 25$ & $283(44.99)$ & $63(56 ; 73)$ & \\
\hline \multicolumn{4}{|l|}{ Skin color } \\
\hline White & $437(69.70)$ & $62(53 ; 70)$ & 0.364 \\
\hline Not white & $190(30.30)$ & $60(53 ; 69)$ & \\
\hline \multicolumn{4}{|l|}{ Marital status } \\
\hline Without partner & $543(86.33)$ & $61(53 ; 70)$ & 0.208 \\
\hline With partner & $86(13.67)$ & $63(54 ; 72)$ & \\
\hline \multicolumn{4}{|l|}{ Work } \\
\hline Yes & $391(62.16)$ & $62(53 ; 70)$ & 0.675 \\
\hline No & $238(37.84)$ & $60(53 ; 70)$ & \\
\hline \multicolumn{4}{|l|}{ Household income $e^{\star}$} \\
\hline$<6 \mathrm{MW}^{* * *}$ & $420(71.79)$ & $62(54 ; 71)$ & 0.004 \\
\hline$\geq 6 \mathrm{MW}$ & $165(28.21)$ & $58(51 ; 68)$ & \\
\hline \multicolumn{4}{|c|}{ Parent's education level - higher education } \\
\hline No & $441(70.11)$ & $62(54 ; 71)$ & 0.009 \\
\hline Yes & $188(29.89)$ & $59(52 ; 68)$ & \\
\hline \multicolumn{4}{|l|}{ College location } \\
\hline Capital & $431(68.52)$ & $60(53 ; 70)$ & 0.103 \\
\hline Elsewhere & $198(31.48)$ & $63(54 ; 70)$ & \\
\hline \multicolumn{4}{|l|}{ Course year } \\
\hline Freshmen & $85(13.51)$ & $63(55 ; 75)$ & 0.173 \\
\hline 1st and 2nd year & $260(41.34)$ & $61(53 ; 69)$ & \\
\hline$\geq 3$ rd year & $284(45.15)$ & $60(53 ; 70)$ & \\
\hline \multicolumn{4}{|l|}{ University } \\
\hline Public & $109(17.33)$ & $56(48 ; 63)$ & $<0.001$ \\
\hline Private & $520(82.67)$ & $62(54 ; 71)$ & \\
\hline \multicolumn{4}{|l|}{ BMI real and perception ${ }^{\star * * *}$} \\
\hline No-obesity & $208(33.07)$ & $64(55 ; 72)$ & 0.001 \\
\hline No-obesity see larger & $377(59.94)$ & $60(53 ; 69)$ & \\
\hline W/ obesity & $7(1.11)$ & $61(48 ; 66)$ & \\
\hline W/ obesity see larger & $37(5.88)$ & $54(46 ; 61)$ & \\
\hline
\end{tabular}

* Differences in total $\mathrm{N}$ due to missing values. ${ }^{* *}$ Mann Whitney test (2 categories) and Kruskal-Wallis (three or more categories). ${ }^{* * *}$ Minimum wages (US\$152.26). ${ }^{* * * *}$ Individuals with obesity with perception of BMI higher than real, differ from two categories of no-obese (those who perceive and those who do not perceive BMI larger than real).

Source: Authors.

Median values and distribution according to the interquartile ranges (IQ25-75) of AFAT and its subscales were, respectively: 61 (53-70); "Social and character disparagement": 19 (1722); "Weight control and blame": 22 (17-26) and "Physical and romantic unattractiveness": 20 (17-24).
Regarding to nutritional status, nearly one in four students was with overweight and $7 \%$ were with obesity. Only one in four students had body perception compatible with their nutritional status, and the majority (65\%) perceived their BMI higher than actual and were dissatisfied with their body (Table 2). There was a difference between 
Table 2. Antifat Attitudes Test (AFAT) median scores according to nutritional status, body image perception and satisfaction of Dietetic major students in São Paulo - Brazil $(n=629)$.

\begin{tabular}{|c|c|c|c|}
\hline Variable & n (\%) & AFAT median & $\mathbf{p}^{*}$ \\
\hline \multicolumn{4}{|l|}{ BMI } \\
\hline median (IQ 25-75) & $22 ; 31(20.37 ; 25.15)$ & -- & \multirow{5}{*}{0.006} \\
\hline Underweight & $44(7.00)$ & $64(53 ; 78)$ & \\
\hline Normal & $418(66.45)$ & $62(54 ; 70)$ & \\
\hline Overweight & $123(19.55)$ & $60(53 ; 69)$ & \\
\hline Obesity & $44(7.00)$ & $55(47 ; 63)$ & \\
\hline \multicolumn{4}{|l|}{ Obesity } \\
\hline No & $585(93.00)$ & $62(54 ; 70)$ & \multirow[t]{2}{*}{0.001} \\
\hline Yes & $44(7.00)$ & $55(47 ; 63)$ & \\
\hline \multicolumn{4}{|l|}{ Body perception } \\
\hline median (IQ 25-75) & $1(0 ; 2)$ & -- & \multirow{5}{*}{0.052} \\
\hline As it is & $124(19.71)$ & $62(53 ; 72)$ & \\
\hline Perceive smaller ${ }^{1}$ & $91(14.47)$ & $65(56 ; 72)$ & \\
\hline Perceive larger $^{2}$ & $287(45.63)$ & $60(53 ; 68)$ & \\
\hline Perceive much larger ${ }^{3}$ & $127(20.19)$ & $60(52 ; 71)$ & \\
\hline \multicolumn{4}{|c|}{ Perceive BMI higher than real } \\
\hline No & $215(34.18)$ & $64(55 ; 72)$ & \multirow[t]{2}{*}{0.009} \\
\hline Yes & $414(65.82)$ & $60(53 ; 68)$ & \\
\hline \multicolumn{4}{|l|}{ Body satisfaction } \\
\hline median (IQ 25-75) & $1(0 ; 3)$ & -- & \multirow{5}{*}{0.750} \\
\hline Yes & $85(13.51)$ & $63(55 ; 70)$ & \\
\hline Desire larger $^{4}$ & $129(20.51)$ & $61(53 ; 72)$ & \\
\hline Desire smaller ${ }^{5}$ & $253(40.22)$ & $62(54 ; 69)$ & \\
\hline Desire much smaller ${ }^{6}$ & $162(25.76)$ & $60(52 ; 70)$ & \\
\hline \multicolumn{4}{|c|}{ Dissatisfaction with high BMI } \\
\hline No & $214(34.02)$ & $62(53 ; 72)$ & \multirow[t]{2}{*}{0.413} \\
\hline Yes & $415(65.98)$ & $61(53 ; 69)$ & \\
\hline
\end{tabular}

${ }^{*}$ Mann Whitney test (two categories) and Kruskal-Wallis (three or more categories). ${ }^{1}$ Difference between actual and perceived figure was -1 to -4 points. ${ }^{2}$ Difference between actual and perceived figure of 1 to 2 points. ${ }^{3}$ Difference between actual and perceived figure of 3 to 7 points. ${ }^{4}$ Dissatisfaction with a desire of a larger silhouette of -1 to -5 points. ${ }^{5}$ Dissatisfaction with a desire of a smaller silhouette of 1 to 2 points. ${ }^{6}$ Dissatisfaction with a desire of a smaller silhouette of 3 to 12 points.

Source: Authors.

the AFAT medians according to the nutritional status and being or not with obesity and perceive themselves to be larger than they really were.

Most of the participants studied in private schools $(82.7 \%)$, in the capital of São Paulo state $(68.5 \%)$, and were at the second semester or later $(45.1 \%)$. There was a difference in the AFAT score according to the type of university $(\mathrm{p}<$ $0.001)$, without difference for students from the capital or not $(p=0.104)$, course year $(p=0.170)$ and between freshmen and seniors $(p=0.06)-$ data not shown.

The linear regression with multiple hierarchical model indicated that male individuals and age $>25$ years, those with household income below six MW, attending college outside the capital and at a private institution had higher scores in total AFAT. In turn, students with obesity who perceived their bodies to be larger than actual, attending the third to the fifth year of the course, had lower scores (Table 3).

The linear regression to "Social and character disparagement" subscale pointed that there was a difference in relation to sex, age and income, and being with obesity and perceiving oneself as being over the real BMI (Table 4).

The analysis of linear regression for "Physical and romantic unattractiveness" subscale, indicated difference in relation to sex and age, and had lower scores for students with obesity and who perceived their body larger than the real one, and higher scores for private institutions (Table 5). 
Table 3. Factors associated with the Antifat Attitude Test (AFAT) ${ }^{\star}$ score in a linear regression model for Dietetic major students in São Paulo - Brazil $(\mathrm{n}=629)$.

\begin{tabular}{|c|c|c|c|c|}
\hline Variable & $\begin{array}{l}\text { Crude model } \\
\text { B (IC 95\%) }\end{array}$ & $\mathbf{p}$ & $\begin{array}{c}\text { Adjusted model }^{\star *} \\
\text { B (IC 95\%) }\end{array}$ & $\mathbf{p}$ \\
\hline \multicolumn{5}{|l|}{ Distal level } \\
\hline \multicolumn{5}{|l|}{ Sex } \\
\hline Female (ref.) & -- & - & & \\
\hline Male & $0.14(0.08 ; 0.21)$ & $<0.000$ & $0.13(0.06 ; 0.19)$ & $<0.001$ \\
\hline \multicolumn{5}{|l|}{ Age (years) } \\
\hline$<25$ (ref.) & -- & - & -- & \\
\hline$\geq 25$ & $0.07(0.03 ; 0.09)$ & $<0.000$ & $0.06(0.03 ; 0.09)$ & $<0.001$ \\
\hline \multicolumn{5}{|l|}{ Household income } \\
\hline$<6 \mathrm{MW}^{\star \star \star}$ (ref.) & -- & -- & -- & \\
\hline$\geq 6 \mathrm{MW}$ & $-0.06(-0.09 ;-0.02)$ & 0.003 & $-0.05(-0.09 ;-0.01)$ & 0.006 \\
\hline Parent's education level - higher education & & & -- & \\
\hline No (ref.) & -- & -- & -- & \\
\hline Yes (higher education) & $-0.05(-0.09 ;-0.02)$ & 0.002 & -- & \\
\hline \multicolumn{5}{|l|}{ Intermediate level } \\
\hline BMI real and perception $* * * *$ & 10 & & & \\
\hline No-obesity (ref.) & -- & -- & -- & \\
\hline No-obesity see larger & $-0.03(-0.07 ; 0.00)$ & 0.058 & $-0.03(-0.06 ;-0.00)$ & 0.084 \\
\hline W/ obesity & $-0.03(-0.18 ; 0.12)$ & 0.734 & $-0.07(-0.22 ; 0.10)$ & 0.481 \\
\hline W/ obesity see larger & $-0.13(-0.20 ;-0.06)$ & $<0.000$ & $-0.15(-0.22 ;-0.08)$ & $<0.001$ \\
\hline \multicolumn{5}{|l|}{ Proximal level } \\
\hline \multicolumn{5}{|l|}{ College location } \\
\hline Capital (ref.) & -- & -- & -- & \\
\hline Elsewhere & $0.02(-0.01 ; 0.06)$ & 0.148 & $0.03(-0.001 ; 0.07)$ & 0.046 \\
\hline \multicolumn{5}{|l|}{ Course year } \\
\hline Freshmen (ref.) & -- & & & \\
\hline 1st and 2nd year & $-0.04(-0.09 ; 0.00)$ & 0.070 & $-0.04(-0.09 ; 0.01)$ & 0.084 \\
\hline$\geq 3$ rd year & $-0.05(-0.10 ; 0.00)$ & 0.051 & $-0.05(-0.10 ;-0.02)$ & 0.041 \\
\hline \multicolumn{5}{|l|}{ University } \\
\hline Public (ref.) & -- & & & \\
\hline Private & $0.10(0.06 ; 0.14)$ & $<0.000$ & $0.08(0.04 ; 0.12)$ & $<0.001$ \\
\hline
\end{tabular}

Source: Authors.

Finally, to "Weight control and guilt" subscale, different scores were observed for sex and age; they were also higher for students with household income below six MW, attending college outside the capital, and private institutions; lower scores were found as the student advanced in the course; and again with lower scores for students with obesity who perceived their bodies larger than actual (Table 6).

\section{Discussion}

It was found a considerable proportion having negative attitudes that should be interpreted as prejudice and stigma which could affect their future professional practice. Based on several findings, some at-risk for prejudice, were identified - such as male sex and older age - which could help addressing educational strategies.

Various studies used the AFAT in other countries ${ }^{30,34-39}$. The AFAT's development study 
Table 4. Factors associated with the Antifat Attitude Test (AFAT)* "social/character disparagement" dimension score in a linear regression model for Dietetic major students in São Paulo - Brazil $(n=629)$.

\begin{tabular}{|c|c|c|c|c|}
\hline Variable & $\begin{array}{c}\text { Crude model } \\
\text { B (IC 95\%) }\end{array}$ & $\mathbf{p}$ & $\begin{array}{c}\text { Adjusted } \\
\text { model }{ }^{\star \star} \\
\text { B (IC 95\%) }\end{array}$ & $\mathbf{p}$ \\
\hline \multicolumn{5}{|l|}{ Distal level } \\
\hline \multicolumn{5}{|l|}{ Sex } \\
\hline Female (ref.) & -- & - & -- & - \\
\hline Male & $0.13(0.06 ; 0.19)$ & $<0.001$ & $0.12(0.05 ; 0.18)$ & $<0.001$ \\
\hline \multicolumn{5}{|l|}{ Age (years) } \\
\hline$<25$ (ref.) & -- & -- & -- & - \\
\hline$\geq 25$ & $0.06(0.03 ; 0.09)$ & $<0.001$ & $0.06(0.03 ; 0.09)$ & $<0.001$ \\
\hline \multicolumn{5}{|l|}{ Household income } \\
\hline$<6 \mathrm{MW}^{\star * \star}$ (ref.) & -- & - & -- & - \\
\hline$\geq 6 \mathrm{MW}$ & $-0.05(-0.08 ;-0.01)$ & 0.012 & $-0.04(-0.08 ;-0.01)$ & 0.020 \\
\hline NS/NR & $-0.05(-0.07 ; 0.06)$ & 0.873 & $-0.01(-0.07 ; 0.05)$ & 0.848 \\
\hline \multicolumn{5}{|l|}{ Intermediate level } \\
\hline \multicolumn{5}{|l|}{ BMI real and perception ${ }^{* * * *}$} \\
\hline No-obesity (ref.) & -- & -- & -- & \\
\hline No-obesity see larger & $-0.03(-0.06 ; 0.01)$ & 0.093 & $-0.03(-0.06 ; 0.01)$ & 0.133 \\
\hline W/ obesity & $-0.03(-0.19 ; 0.12)$ & 0.669 & $-0.07(-0.23 ; 0.07)$ & 0.327 \\
\hline W/ obesity see larger & $-0.08(-0.16 ;-0.01)$ & 0.023 & $-0.09(-0.17 ;-0.02)$ & 0.008 \\
\hline \multicolumn{5}{|l|}{ Proximal level } \\
\hline \multicolumn{5}{|l|}{ University } \\
\hline Public (ref.) & -- & - & -- & - \\
\hline Private & $0.05(0.01 ; 0.09)$ & 0.021 & -- & - \\
\hline
\end{tabular}

Source: Authors.

applied a 47 statements scale in American college students ${ }^{30}$ and later in physical education undergraduate students and physical trainers ${ }^{34}$. However, the first study utilized a 47-item AFAT and a scoring system different from later studies with undergraduate students that used 34 items ${ }^{35,36}$. Other studies also utilized the 34-item AFAT $^{37,38}$, while other study with a sample of nurses used only the "Weight control" subscale ${ }^{39}$. Thus, diverse ways of assessing scores have been observed, which does not allow adequate comparisons. Therefore, considering the existing data about the AFAT, it is not possible to state that there is a general difference between American and Brazilian students, or between students of diverse courses and nutrition - which would require a larger number of studies with different places and populations.
However, other studies - using different scales - with nutrition undergraduates found that they held more anti-fat attitudes ${ }^{8}$, or that they may have the same negative attitudes as other areas ${ }^{6}$. Anyway, various studies point to the existence of negative attitudes among nutrition students ${ }^{7-10}$ and dietitians $s^{4,6,10,12,40,41}$ toward individuals with obesity. One of these studies did not find difference in negative attitudes between dietitians and nutrition students ${ }^{10}$.

On the other hand, neutral or positive attitudes of dietitians toward individuals with overweight were also found ${ }^{11,42}$. A review about weight-related stigma by dietitians showed that six out of eight studies pointed to the stigma expressed by these professionals - focused on internal causes rather than genetics or biology as causes of obesity ${ }^{4}$. That is, overweight is seen as a 
Table 5. Factors associated with the Antifat Attitude Test (AFAT)* "physical and romantic attractiveness" dimension score in a linear regression model for Dietetic major students in São Paulo - Brazil $(\mathrm{n}=629)$.

\begin{tabular}{|c|c|c|c|c|}
\hline Variable & $\begin{array}{l}\text { Crude model } \\
\text { B (IC 95\%) }\end{array}$ & $\mathbf{p}$ & $\begin{array}{c}\text { Adjusted } \\
\text { model }{ }^{\star *} \\
\text { B (IC 95\%) }\end{array}$ & $\mathbf{p}$ \\
\hline \multicolumn{5}{|l|}{ Distal level } \\
\hline \multicolumn{5}{|l|}{ Sex } \\
\hline Female (ref.) & -- & - & -- & \\
\hline Male & $0.15(0.07 ; 0.23)$ & $<0.001$ & $0.14(0.06 ; 0.22)$ & $<0.001$ \\
\hline \multicolumn{5}{|l|}{ Age (years) } \\
\hline$<25$ (ref.) & -- & - & -- & - \\
\hline$\geq 25$ & $0.07(0.04 ; 0.12)$ & $<0.001$ & $0.07(0.03 ; 0.11)$ & $<0.001$ \\
\hline \multicolumn{5}{|l|}{ Household income } \\
\hline$<6 \mathrm{MW}^{\star \star \star}$ (ref.) & -- & - & -- & - \\
\hline$\geq 6 \mathrm{MW}$ & $-1.66(-2.71 ;-0.62)$ & 0.002 & -- & \\
\hline \multicolumn{5}{|l|}{ Intermediate level } \\
\hline \multicolumn{5}{|l|}{ BMI real and perception ${ }^{\star * * *}$} \\
\hline No-obesity (ref.) & -- & - & -- & -- \\
\hline No-obesity see larger & $-0.03(-0.07 ; 0.01)$ & 0.167 & $-0.02(-0.07 ; 0.02)$ & 0.268 \\
\hline W/ obesity & $-0.10(-0.29 ; 0.09)$ & 0.302 & $-0.15(-0.34 ; 0.04)$ & 0.126 \\
\hline W/ obesity see larger & $-0.13(-0.22 ;-0.04)$ & 0.006 & $-0.13(-0.22 ;-0.05)$ & 0.003 \\
\hline \multicolumn{5}{|l|}{ Proximal level } \\
\hline \multicolumn{5}{|l|}{ College location } \\
\hline Capital (ref.) & -- & - & -- & - \\
\hline Elsewhere & $0.03(-0.01 ; 0.07)$ & 0.189 & $0.04(-0.01 ; 0.08)$ & 0.085 \\
\hline \multicolumn{5}{|l|}{ Course year } \\
\hline Freshman (ref.) & -- & - & -- & - \\
\hline 1st and 2nd year & $-0.04(-0.10 ;-0.02)$ & 0.233 & -- & \\
\hline$\geq 3$ rd year & $-0.03(-0.09 ;-0.03)$ & 0.352 & -- & \\
\hline \multicolumn{5}{|l|}{ University } \\
\hline Public (ref.) & -- & - & -- & - \\
\hline Private & $0.06(0.01 ; 0.12)$ & 0.017 & $0.06(0.01 ; 0.11)$ & 0.031 \\
\hline
\end{tabular}

$B=$ coefficient of linear regression (mean difference between the evaluated category and the reference category); ref. $=$ reference category for comparison. ${ }^{*} \mathrm{AFAT}$ in logarithmic scale (best fit), hierarchical linear regression modeling (adjusted R2 $=6,0 \%$ ). ${ }^{* *}$ The regression coefficients were adjusted for the variables within the hierarchical level itself and also for the higher-level variables that remained in the model. ${ }^{* * *}$ Minimum wages (US\$152.26). ${ }^{* * *}$ Individuals with obesity with perception of BMI larger than real, differ from two categories of no-obese (those who perceive and those who do not perceive BMI higher than real).

Source: Authors.

malleable condition and individuals with obesity are responsible for it.

In the present study, the AFAT scores were higher for male students, pointing to more negative attitudes. Other studies also found that the AFAT total score was higher for men, with difference for the "Social and character disparagement"30; for "Physical and romantic unattractiveness" 34 and for all subscales ${ }^{35}$. Although the number of men was small, the finding of more negative attitudes among this population is noteworthy, which suggests the need for clarifying this relation in assessments that include an equivalent number of men in the sample. The influence of sex was not assessed in other studies that were carried out with dietitians and nutrition student $t^{6,7,10,11,43,44}$; except one, but which did not find significance ${ }^{8}$.

Lewis et al. point out that studies that found more negative attitudes among female used assessment scales that prioritized the participant's concern with his/her excess of weight, which is 
Table 6. Factors associated with the Antifat Attitude Test (AFAT)* "weight control/blame" dimension score in a linear regression model for Dietetic major students in São Paulo - Brazil $(n=629)$.

\begin{tabular}{|c|c|c|c|c|}
\hline Variable & $\begin{array}{c}\text { Crude model } \\
\text { B (IC 95\%) }\end{array}$ & $\mathbf{p}$ & $\begin{array}{c}\text { Adjusted } \\
\text { model }{ }^{\star *} \\
\text { B (IC 95\%) }\end{array}$ & $\mathbf{p}$ \\
\hline \multicolumn{5}{|l|}{ Distal level } \\
\hline \multicolumn{5}{|l|}{ Sex } \\
\hline Female (ref) & -- & - & -- & - \\
\hline Male & $3.16(1.32 ; 4.99)$ & 0.001 & $2.86(1.03 ; 4.69)$ & 0.002 \\
\hline \multicolumn{5}{|l|}{ Age (years) } \\
\hline$<25$ (ref.) & -- & - & -- & - \\
\hline$\geq 25$ & $1.33(0.41 ; 2.24)$ & 0.004 & $1.21(0.31 ; 2.11)$ & 0.009 \\
\hline \multicolumn{5}{|l|}{ Household income } \\
\hline$<6 \mathrm{MW}^{\star \star \star}$ (ref.) & -- & - & -- & - \\
\hline$\geq 6 \mathrm{MW}$ & $-1.66(2.71 ;-0.62)$ & 0.002 & $-1.56(-2.60 ;-0.53)$ & 0.003 \\
\hline \multicolumn{5}{|l|}{ Intermediate level } \\
\hline \multicolumn{5}{|l|}{ BMI real and perception ${ }^{\star * * *}$} \\
\hline No-obesity (ref.) & -- & - & -- & - \\
\hline No-obesity see larger & $-0.87(-1.85 ; 0.11)$ & 0.081 & $-0.81(-1.78 ; 0.17)$ & 0.104 \\
\hline W/ obesity & $0.54(-3.83 ; 4.91)$ & 0.809 & $-0.43(-4.75 ; 3.89)$ & 0.844 \\
\hline W/ obesity see larger & $-3.59(-5.62 ;-1.56)$ & 0.001 & $-3.97(-5.97 ;-1.95)$ & $<0.001$ \\
\hline \multicolumn{5}{|l|}{ Proximal level } \\
\hline \multicolumn{5}{|l|}{ College location } \\
\hline Capital (ref.) & -- & - & -- & - \\
\hline Elsewhere & $0.92(-0.07 ; 1.89)$ & 0.068 & $1.09(0.14 ; 2.04)$ & 0.024 \\
\hline \multicolumn{5}{|l|}{ University } \\
\hline Public (ref.) & -- & - & -- & - \\
\hline Private & $3.48(2,30 ; 4,65)$ & $<0.001$ & $2.90(1.69 ; 4.11)$ & $<0.001$ \\
\hline \multicolumn{5}{|l|}{ Course year } \\
\hline Freshman (ref.) & -- & - & -- & - \\
\hline 1st and 2nd year & $-1.79(-3.21 ;-0.36)$ & 0.014 & $-1.69(-3.05 ;-0.33)$ & 0.015 \\
\hline$\geq 3$ rd year & $-2.08(-3.50 ;-0.67)$ & 0.004 & $-1.96(-3.32 ;-0.60)$ & 0.005 \\
\hline
\end{tabular}

$B=$ coefficient of linear regression (mean difference between the evaluated category and the reference category); ref $=$ reference category for comparison. ${ }^{*} \mathrm{AFAT}$ in logarithmic scale (best fit), hierarchical linear regression modeling (adjusted R2 $=10,5 \%$ ). ** The regression coefficients were adjusted for the variables within the hierarchical level itself and also for the higher-level variables that remained in the model. ${ }^{* * *}$ Minimum wages (US\$152.26). ${ }^{* * * *}$ Individuals with obesity with perception of BMI larger than real, differ from two categories of no-obese (those who perceive and those who do not perceive BMI higher than real).

Source: Authors.

more frequently found in women ${ }^{30}$. Thus, assessing the respondents' satisfaction with their own body may be important.

In the present study, the body image was assessed to determine whether (besides the nutritional status itself) it was associated with or had an influence on the attitudes toward individuals with obesity. The high frequency found of altered perception and dissatisfaction corroborate the results of previous studies with Brazilian undergraduates $^{45,46}$. A higher degree of misperception was found in women, as well as body dissatisfaction, and women with overweight and obesity ex- hibited more misperception compared to women with underweight. In any case, body dissatisfaction did not influence the presence of negative attitudes in the regression analysis with AFAT total and subscales scores, but the perception of having a BMI higher than the actual one.

The multiple regression analyses indicated that for AFAT total and three subscales, the scores were lower for the ones with obesity and who perceived their bodies larger than actual. Schwartz et al. found that all weight and nutritional status groups exhibited negative attitudes toward individuals with obesity but those with 
higher BMI exhibited less prejudice ${ }^{47}$. This suggests that people who experienced a situation of being with obesity think of these issues differently. Other previous studies using the AFAT did not find a relationship between the BMI and the total score ${ }^{30,35}$ and a low correlation between the BMI and the "Physical and romantic unattractiveness" and "Weight control and blame" subscales ${ }^{36}$.

Using distinct scales, other studies with dietitians and nutrition students found a weak and negative relation with $\mathrm{BMI}^{10}$ or absence of relationship between BMI and anti-fat attitudes ${ }^{6,8}$. Jung et al. stated that the professional's own weight can make a difference ${ }^{4}$, but in the present study the difference between the AFAT medians for nutritional status was maintained in the regression analysis, and there was no relationship with body dissatisfaction, only fewer negative attitudes among those who, in terms of perception, had a BMI of obesity and perceived themselves to be larger than actual.

Regarding age and course year, the studies that used the AFAT did not assess their relationship with the presence of anti-fat attitudes. But Swift et al. found that age contributed to explain less than $2 \%$ of variability of prejudice toward obesity, and it was found less prejudice in the students at the last year of the course compared with the first one ${ }^{8}$.

Decreasing scores for total AFAT as the school year advances is somehow expected. As students advance in the nutrition course, their understanding about the complexity of the obesity etiology increases, and they are introduced to more humanized management strategies. But some studies did not find difference in age and more experienced individuals ${ }^{4}$ and it is worrisome to note that studies conducted with dietitians also found prejudice and negative attitudes ${ }^{25}$. Such results bring to light the question whether courses are providing the necessary approaches to reduce weight bias.

With regard to the "Social and character disparagement" and "Physical and romantic unattractiveness" subscales, the analyses indicated that older individuals and men exhibited more negative attitudes, and that heavier individuals held fewer negative attitudes. Finally, the "Weight control and blame" subscale presented higher scores for private universities and the male sex.

With respect to the male sex, we can speculate that the higher scores for "Physical and romantic unattractiveness" and "Weight control and blame" indicate that men tend to value looks more in relationships and blame individuals with obesity more for their condition - a fact that deserves more investigation. The relation with university indicates that students differ in attributing to the individual the responsibility, a view that may be based on possible differences in the undergraduate curriculum content ${ }^{48}$. In Brazil, the fact that in public universities the entrance exams are much more difficult makes that they often receive individuals who studied in better schools, whose parents have a college degree, and who do not work during the course, thus having full time to devote to academic activities. Furthermore, public universities in Brazil usually offer more hours of disciplines - which may contribute to a more comprehensive and in-depth education on the causes of obesity. The differences found with respect to household occupational income, university location and the parent's educational level also account for such differences in the Brazilian undergraduates' profile: we have more private colleges and universities, with differentiated teaching quality and student's profile.

Overall, the subscale scores indicated a correlation with the sample characteristics, in a similar manner to what occurred with total AFAT, except for the course year, which influenced only the total score and the "Weight control and blame"; and university did not just influence the "Physical and romantic attractiveness" subscale.

As limitations of the study, we highlight that: 1) it should be considered that the attitudes assessed in this work were the explicit ones, with limited assessment since they are consciously reported and subject to the desire of social acceptance and depend on self-reporting (which requires to be conscious of negative attitudes). This way, individuals may not report accurately the negative attitudes toward a group if they think that it is not appropriate to do so. Thus, the results of this study should be interpreted in the light of use of one scale, which always limit the responses to the context and the response options offered, and which assessed explicit attitudes. 2) The small number of men should also be considered as a limitation (but it is a characteristic of undergraduate nutrition courses); and 3) a non-probabilistic sample. On the other hand, we highlight as strengths of the study that, first of all, as far as we know, this is the first study that investigated negative attitudes toward obesity among nutrition undergraduates in Brazil using the AFAT - a specific tool adapted for Brazilian-Portuguese. Moreover, 1) implicit attitudes could have a less biased and more comprehensive assessment as they access unconscious attitudes by means of automatic 
mental associations. Teachman and Brownell ${ }^{49}$ assessed anti-fat attitudes of health professionals in both ways and found that the results of the implicit and explicit assessments were divergent in the sample regarding the stereotypes of thin and fat people. 2) the study brings the data, perhaps unprecedented (to be better explored) of differences in anti-fat attitudes of male students in the graduation in nutrition; and 3) worked within a broader study (NutriHS), with a large group of students and with adequate effect and high power of the test for the sample.

The findings of negative attitudes among these students are similar to others in diverse countries. Considering the high prevalence of obesity and the presence of anti-fat attitudes among students and health professionals toward obesity and individuals with obesity, the theme of this study is of vital importance for Public Health, considering that these attitudes jeopardize the work efforts in treating obesity ${ }^{16,50}$. The presence and perception of negative attitudes related to weight increase the likelihood of adherence to unhealthy and disordered eating behaviors - such as eating too much, poor physical activity, and difficulties in reducing weight and maintaining reduced weight and the stigma imperils healthcare and patients feel disrespected and poorly cared $\mathrm{d}^{27,50-55}$.

Also, it is known the deleterious effects of weight bias among health professionals, which include less patient-centered communication, less time spent in contact with patients, and less information provided ${ }^{27}$. The problem of weight bias held by health professionals is so important that several studies have discussed educational interventions in an attempt to reduce it. Up to now, there has been no approach that proved to be effective in reducing weight bias among healthcare students and practitioners ${ }^{56}$. An issue to be considered is that health students and professionals live in a prejudice-laden society, and to change this, systemic social norms are necessary.

Information on genetic, environmental and social causes of obesity - as well as their interactions - should be presented convincingly during these professionals' training course along with the causes and treatments of obesity ${ }^{4,57}$. Working on changing beliefs alone has not been fully effective, but working on social consensus and norms appears to be promising, in addition to the need to consider additional psychological mechanisms that underpin the prejudice ${ }^{58,59}$.

Health professionals must be aware of their own attitudes and behaviors toward individuals af- fected by obesity and how much such negative stereotypes may impact care and engagement. If dietitians believe that their patients do not have the motivation and are responsible for their condition, it will be difficult to plan strategies to provide adequate support and counseling in treating obesity ${ }^{4}$.

As undergraduates are still learning previous education may be valuable in reducing weight bias; therefore, even a curriculum review should be considered in order to optimize the quality of care $^{27}$, considering that current training fails in approaching the obesity stigma ${ }^{60}$.

Education on weight stigma should include the discussion that care does not include technical and theoretical skills only but also empathy, adequate communication and compassion ${ }^{4,35,36}$. Future research studies should assess representative groups of dietitians, comparing different contexts relating to age, nutritional status, professional education and experience.

\section{Conclusion}

Nutrition undergraduates in São Paulo - Brazil have negative attitudes toward obesity and individuals affected by obesity, which can be understood as prejudice and stigma.

For the AFAT total score, men and older students exhibited more negative attitudes, and those who perceived themselves to be above the actual BMI, with higher household income, and studying in more advanced college years, exhibited fewer negative attitudes.

Male and older students had a higher score for the "Social and character disparagement" subscale, and a lower score was achieved by those affected with obesity, who perceived to be above actual BMI, and with higher income. Similarly, male and older students exhibited a more stigmatized view to "Physical and romantic unattractiveness", as well as those from private institutions; and a less stigmatized view by those affected by obesity and who perceived their body greater than it actually was. Male and older students also exhibited more negative attitudes for "Weight control and blame", added to the ones from colleges located outside the capital, and private institutions; lower scores were obtained by students in more advanced years in the course, with higher income and those with obesity who perceived to be above actual BMI.

The results raise the need for education on obesity stigma in undergraduate courses of nutrition in Brazil - as well as in other countries. 


\section{Collaborations}

MS Alvarenga was responsible for conception, data analyses and interpretation, drafting the article and revising it critically. AA Obara was responsible for conception, data collection and organization, and participated of analyses and interpretation of this data. GA Takeda contributed for the drafting and revision of the article. SRG Ferreira participated of the conception and was responsible for the NutriHS project and database.

\section{References}

1. Thomas SL, Hyde J, Karunaratne A, Herbert D, Komesaroff PA. Being 'fat' in today's world: a qualitative study of the lived experiences of people with obesity in Australia. Health Expect 2008; 11(4):321-330.

2. Puhl RM, Heuer CA. The stigma of obesity: a review and update. Obesity 2009; 17:941-964.

3. Sikorski C, Luppa M, Glaesmer H, Brähler E, König HH, Riedel-Heller SG. Attitudes of health care professionals toward female obese patients. Obes Facts 2013; 6(6):512-522.

4. Jung FU, Luck-Sikorski C, Wiemers N, Riedel-Heller SG. Dietitians and nutritionists: stigma in the context of obesity. A systematic review. PLoS One 2015; 10(10):e0140276.

5. Phelan SM, Burgess DJ, Yeazel MW, Hellerstedt WL, Griffin JM, van Ryn M. Impact of weight bias and stigma on quality of care and outcomes for patients with obesity. Obes Rev 2015; 16(4):319-326.

6. Berryman DE, Dubale GM, Manchester DS, Mittelstaedt R. Dietetics students possess negative attitudes toward obesity similar to nondietetics students. J Am Diet Assoc 2006; 106:1678-1682.

7. Puhl RM, Wharton C, Heuer CA. Weight bias among dietetics students: implications for treatment practices. J Am Diet Assoc 2009; 109(3):438-444.

8. Swift JA, Hanlon S, El-Redy L, Puhl RM, Glazebrook C. Weight bias among UK trainee dietitians, doctors, nurses and nutritionists. J Hum Nutr Diet 2012; 26(4):395-402.

9. Bacardi-Gascon M, Jimenez-Cruz A, Castillo-Ruiz O, Bezares-Sarmiento V, Leon-Gonzalez JM. Fat phobia in Mexican nutrition students. Nutr Hosp 2015; 32(6):2956-2957.

10. Oberrieder H, Walker R, Monroe D, Adeyanju M. Attitude of dietetics students and registered dietitians toward obesity. J Am Diet Assoc 1995; 95(8):914-916.

11. Harvey EL, Summerbell CD, Kirk SFL, Hill AJ. Dietitians' views of overweight and obese people and reported management practices. J Hum Nutr Dietet 2002; 15:331-347.

12. Diversi TM, R. Hughes R, Burke KJ. The prevalence and practice impact of weight bias amongst Australian dietitians. Obes Sci Pract 2016; 2(4):456-465.

13. Puhl RM, Latner, J. Weight bias: new science on an significant social problem. Obesity 2008; 16(Suppl. 2):S1-S2.

14. Brewis A, SturtzSreetharan C, Wutich A. Obesity stigma as a globalizing health challenge. Global health 2018; 14(1):20.

15. Pearl RL. Weight bias and stigma: public health implications and structural solutions. Soc Issues Policy Rev 2018; 12(1):146-182.

16. Crandall CS, D’Anello S, Sakalli N, Lazarus E, Nejtardt GW, Feather NT. An attribution-value model of prejudice: anti-fat attitudes in six nations. Pers Soc Psychol Bull 2001; 27:30-37.

17. Puhl RM, Latner JD, O'Brien K, Luedicke J, Danielsdottir S, Forhan M. A multinational examination of weight bias: predictors of anti-fat attitudes across four countries. Int J Obesity 2015; 39(7):1166-1173.

18. Hilbert A. Weight stigma reduction and genetic determinism. PLoS One 2016; 11(9):e0162993. 
19. Puhl RM, Heuer CA. Obesity Stigma: Important Considerations for Public Health. Am J Public Health 2010; 100(6):1019-1028.

20. Tomiyama AJ, Carr D, Granberg EM, Major B, Robinson E, Sutin AR, Brewis A. How and why weight stigma drives the obesity 'epidemic' and harms health. BMC Med 2018; 16(1):123.

21. Lee JA, Pausé CJ. Stigma in practice: barriers to health for fat women. Front Psychol 2016; 7:2063.

22. Pomeranz JL. A historical analysis of public health, the law, and stigmatized social groups: the need for both obesity and weight bias legislation. Obesity 2008; 16(2):93-103.

23. Hansson LM, Rasmussen F. Attitudes towards obesity in the Swedish general population - The role of one's own body size, weight satisfaction, and controllability beliefs about obesity. Body Image 2013; 11(1):43-50.

24. World Health Organization (WHO). Global Health Observatory (GHO) data. 2019. [cited 2020 Oct 15]. Available from: https://www.who.int/gho/ncd/risk_ factors/overweight_obesity/obesity_adults/en/

25. Cori GC, Petty MLB, Alvarenga MS. Atitudes de nutricionistas em relação a indivíduos obesos - um estudo exploratório. Cien Saude Colet 2015; 20(2):9-20.

26. Obara AA, Vivolo SRGF, Alvarenga MS. Preconceito relacionado ao peso na conduta nutricional: um estudo com estudantes de nutrição. Cad Saude Publica 2018; 34(8):e00088017.

27. Alberga AS, Russell-Mayhew S, Ranson KM, McLaren L. Weight bias: a call to action. J Eat Disord 2016; 4:34.

28. Folchetti LD, da Silva IT, de Almeida Pititto B, Ferreira SR. The e-NutriHS: a web-based system for a Brazilian cohort study. Stud Health Technol Inform 2015; 216:876.

29. World Health Organization (WHO). Body mass index [Internet]. [cited 2020 Oct 15]. Available from: http:// www.euro.who.int/en/health-topics/disease-prevention/nutrition/a-healthy-lifestyle/body-mass-index -bmi

30. Lewis RJ, Cash TF, Jacobi L, Bubb-Lewis C. Prejudice toward fat people: the development and validation of the Antifat Attitudes Test. Obes Res 1997; 5(4):297307.

31. Lacroix E, Alberga A, Russell-Mathew S, McLaren L, von Ranson K. Weight bias: a systematic review of characteristics and psychometric properties of self-report questionnaires. Obesity facts 2017; 10(3):223237.

32. Obara AA, Alvarenga MS. Adaptação transcultural da Escala de Atitudes Antiobesidade para o português do Brasil. Cien Saude Colet 2018; 23(5):1507-1520.

33. Kakeshita IS, Silva AIP, Zanatta DP, Almeida SS. Construção e fidedignidade teste-reteste de escalas de silhuetas brasileiras para adultos e crianças. Psic Teor e Pesq 2009; 25(2):263-270.

34. Chambliss HO, Finley CE, Blair SN. Attitudes toward obese individuals among exercise science students. Med Sci Sports Exerc 2004; 36(3):468-474.

35. Rukavina PB, Li W, Rowell MB. A service learning based intervention to change attitudes toward obese individuals in kinesiology pre-professionals. Soc Psychol Educ 2008; 11:95-112.
36. Rukavina PB, Li W, Shen B, Sun H. A service learning based project to change implicit and explicit bias toward obese individuals in kinesiology pre-professionals. Obes Facts 2010; 3(2):117-26.

37. Langdon J, Rukavina P, Greenleaf C. Predictors of obesity bias among exercise science students. $A d v$ Physiol Educ 2016; 40(2):157-164.

38. Wijayatunga NN, Kim Y, Butsch WS, Dhurandhar EJ. The effects of a teaching intervention on weight bias among kinesiology undergraduate students. Int $J$ Obes 2019; 43(11):2273-2281.

39. Tanneberger A, Ciupitu-Plath C. Nurses' weight bias in caring for obese patients: do weight controllability beliefs influence the provision of care to obese patients? Clin Nurs Res 2018; 27(4):414-432.

40. Edelstein S, Silva NMS, Mancini LBS. Obesity bias among dietitians by using the Fat People Thin People Implicit Association Test. Top Clin Nut 2009; 24(1):67-72.

41. Hellbardt M, Riedel-Heller SG, Sikorski C. Dieticians' attitudes towards obese patients. Ernaehrungs Umschau international 2014; 61(5):78-81.

42. McArthur LH, Ross JK. Attitudes of registered dietitians toward personal overweight and overweight clients. J Am Diet Assoc 1997; 97(1):63-66.

43. Campbell K, Crawford D. Management of obesity: attitudes and practices of Australian dietitians. Int $\mathrm{J}$ Obes 2000; 24(6):701-710.

44. Stone O, Werner P. Israeli Dietitians' professional stigma attached to obese patients. Qual Health Res 2012; 22(6):768-776.

45. Souza QJOV, Rodrigues AM. Comportamento de risco para ortorexia nervosa em estudantes de nutrição. J Bras Psiquiatr 2014; 63(3):200-204.

46. Alvarenga MS, Philippi ST, Lourenco BH, Sato PM, Scagliusi FB. Insatisfação com a imagem corporal em universitárias Brasileiras. J Bras Psiquiatr 2010; 59(1):44-51.

47. Schwartz MB, Vartanian LR, Nosek BA, Brownell KD. The influence of one's own body weight on implicit and explicit anti-fat bias. Obesity 2006; 14(3):440-447.

48. Koritar P, Alvarenga MS. Relevant factors to healthy eating and to be healthy from the perspective of $\mathrm{Nu}$ trition students. Demetra: Food, Nutrition \& Health 2017; 12(4):1031-1052.

49. Teachman BA, Brownell KD. Implicit anti-fat bias among health professionals: is anyone immune? Int $\mathrm{J}$ Obes 2001; 25(10):1525-1531.

50. Flint S. Obesity stigma: prevalence and impact in healthcare. British Journal of Obesity 2015; 1:14-18.

51. Puhl R, Suh Y. Health consequences of weight stigma: implications for obesity prevention and treatment. Curr Obes Rep 2015; 4(2):182-190.

52. O’Brien KS, Latner JD, Puhl RM, Vartanian LR, Giles $\mathrm{C}$, Griva K, Carter A. The relationship between weight stigma and eating behavior is explained by weight bias internalization and psychological distress. Appetite 2016; 102:70-76.

53. Sutin A, Robinson E, Terracciano A. Weight discrimination and unhealthy eating-related behaviors. Appetite 2016; 102:83-89. 
54. Brewis AA. Stigma and the perpetuation of obesity. Soc Sci Med 2014; 118:152-158.

55. Tomiyama AJ. Weight stigma is stressful. A review of evidence for the Cyclic Obesity/Weight-Based Stigma model. Appetite 2014; 82:8-15

56. Alberga AS, Pickering BJ, Alix Hayden K, Ball GD, Edwards A, Jelinski S, Nutter S, Oddie S, Sharma AM, Russell-Mayhew S. Weight bias reduction in health professionals: a systematic review. Clinical Obesity 2016; 6(3):175-188.

57. O'Brien KS, Latner JD, Ebneter D, Hunter JA. Obesity discrimination: the role of physical appearance, personal ideology, and anti-fat prejudice. Int $J$ Obes 2013; 37:455-460.

58. Daníelsdóttir S, O’Brien KS, Ciaoc A. Anti-fat prejudice reduction: a review of published studies. Obes Facts 2010; 3(1):47-58.

59. O’Brien KS, Puhl RM, Latner JD, Mir AS, Hunter JA. Reducing anti-fat prejudice in preservice health students: a randomized trial. Obesity 2010; 18(11):21382144.

60. Swift JA, Tischler V, Markham S, Gunning I, Glazebrook C, Beer C, Puhl R. Are anti-stigma films a useful strategy for reducing weight bias among trainee healthcare professionals? Results of a pilot randomized control trial. Obes Facts 2013; 6(1):91-102.

Article submitted 30/10/2020

Approved 15/03/2021

Final version submitted 17/03/2021

Chief editors: Romeu Gomes, Antônio Augusto Moura da Silva 